
8 Research Square
Preprints are preliminary reports that have not undergone peer review.
They should not be considered conclusive, used to inform clinical practice, or referenced by the media as validated information.

\title{
Impact of internal variability on recent opposite trends in wintertime temperature over the Barents- Kara Seas and central Eurasia
}

\section{Sai Wang}

China Academy of Meteorological Sciences

Wen Chen ( $\nabla$ chenw@mail.iap.ac.cn )

Institute of Atmospheric Physics Chinese Academy of Sciences https://orcid.org/0000-0001-93279079

\section{Research Article}

Keywords: warm Arctic-cold Eurasia, internal variability, SST, atmospheric variability

Posted Date: February 22nd, 2021

DOI: https://doi.org/10.21203/rs.3.rs-189593/v1

License: (c) (i) This work is licensed under a Creative Commons Attribution 4.0 International License. Read Full License

Version of Record: A version of this preprint was published at Climate Dynamics on November 30th, 2021. See the published version at https://doi.org/10.1007/s00382-021-06077-0. 


\section{Abstract}

The large ensembles of the IPSL-CM6A-LR model output for the historical forcing experiment were employed to investigate the role of internal variability in the formation of the recent "warm Arctic-cold Eurasia" trend pattern in winter surface air temperature (SAT). In the simulations, the winter SAT trends during 1991-2014 display remarkable inter-member diversity over the Barents-Kara Seas region and central Eurasia, suggesting an important role played by internal variability. It is indicated that internally generated SAT trends over the Barents-Kara Seas are induced mainly by the change in local sea surface temperature (SST) trends. Furthermore, we find that the warming trend over the Barents-Kara Seas can induce an anomalous anticyclone over northern Eurasia, which in turn can contribute positively to the warming anomalies over the Barens-Kara Seas, but cannot account for the cooling trend over central Eurasia. The cooling trend over central Eurasia can be attributed to the negative Arctic Oscillation (AO)like atmospheric circulation pattern, which is independent of the climate change over the Arctic. Therefore, the observed opposite winter SAT trends over the Barents-Kara Seas and central Eurasia arise partly from the linear combination of high SST trends over the Barents-Kara Seas and decline in the winter $\mathrm{AO}$ index.

\section{Introduction}

Since the 1990s, rapid surface warming has occurred over the Arctic region (Polyakov et al. 2002; Johannessen et al. 2004; Serreze et al. 2008; Screen and Simmonds 2010b; Screen and Simmonds 2010a; Serreze and Barry 2011). During boreal winter, the strongest surface warming signal can be observed over the Barents-Kara Seas (Kug et al. 2015; Park et al. 2015; Wang et al. 2020b). Over the same period, cooling trends have been observed in mid-latitudes, especially over central Eurasia (Wu et al. 2011; Cohen et al. 2012a; Cohen et al. 2012b; Liu et al. 2012). The pattern of this Northern Hemisphere temperature signal has been referred to as the "warm Arctic-cold continents" pattern (Overland et al. 2010; Cohen et al. 2013; Cohen et al. 2014).

The occurrence of the "warm Arctic-cold continents" trend pattern is accompanied by recovery of the Siberian high (Jeong et al. 2011; Wu et al. 2011) and enhancement of stationary Rossby wave activity over the northern part of Eurasia (Wang et al. 2020e). It is well recognized that the decrease in winter surface air temperature (SAT) over mid-latitudes has arisen from increased waviness in the atmospheric flow (Wang and Chen 2013; Mori et al. 2014; Sun et al. 2016). However, the causality between this increased waviness in the atmospheric flow and Arctic warming is disputed. Some studies have reported that the colder continental temperatures and associated change in atmospheric circulation may be caused by Arctic sea-ice loss and Arctic warming (Tang et al. 2013; Mori et al. 2014; Wang et al. 2020d). For example, Liu et al. (2012) reported that Arctic sea-ice decline can excite negative Arctic Oscillation (AO)-like structural circulation anomalies, which in turn result in more frequent episodes of blocking patterns and cold surges over large parts of northern continents. Some modelling studies have also reported that sea-ice reduction over the Barents-Kara Seas may decrease winter SAT over central Eurasia (Honda et al. 2009; Mori et al. 2014). On the contrary, some studies indicate that the warmer Arctic is a 
consequence, not a cause, of the increased waviness in the atmospheric flow (Trenberth et al. 2014). For example, some studies have indicated that recent recovery of the Siberian high (Feng and Wu 2015; Wang et al. 2020b) can contribute positively to the warming trend over the Barents-Kara Seas. Furthermore, some studies have indicated that most of the winter SAT and sea-ice trends can be attributed to internal atmospheric variability (Park et al. 2015; Gong et al. 2017).

The internally generated variability can be extracted using a given climate model with large ensemble simulations forced by the same external forcing (Deser et al. 2012). This methodology has been adopted to study the impact of internally generated variability on regional climate changes over periods of several decades (Deser et al. 2016; Wang et al. 2018; Ding et al. 2019; Hu et al. 2019). For example, previous studies have investigated the impacts of internal atmospheric variability on the SAT trends over North American and East Asian regions during boreal winter and summer (Deser et al. 2016; Hu et al. 2019). Ding et al. (2019) presented an important internal mechanism arising from low-frequency Arctic atmospheric variability in models that can cause substantial summer sea-ice loss in recent decades.

Adopting the methodology formulated by Deser et al. (2012), we examine the influence of internal variability on the winter SAT trends over the Barents-Kara Seas and central Eurasia, separately, and reveal whether the warming trend over the Barents-Kara Seas and cooling trend over central Eurasia are caused by a common internal driver or independent ones.

The rest of the paper is organized as follows: Sect. 2 describes the observational data, model outputs and methodology employed in this study. Section 3 describes the results. Section 4 gives a summary and a discussion.

\section{Data And Methods}

The present study employs monthly mean atmospheric reanalysis data from ERA-Interim, which span from 1 January 1979 to 31 August 2019 and are on horizontal grids of $2.5^{\circ} \times 2.5^{\circ}$ (Dee et al. 2011). The analysis in this paper uses 31-member ensemble simulations to evaluate the role of internal variability in observed winter temperature trends. The simulations were conducted by the IPSL-CM6A-LR model, set up and developed by the Institute Pierre-Simon Laplace (IPSL) Climate Modelling Centre for Phase 6 of the Coupled Model Intercomparison Project (Eyring et al. 2016). Each of the ensemble members were forced by the same historical radiative forcing but differed in their initial atmospheric conditions. More information about the IPSL-CM6A-LR model is provided in Boucher et al. (2020). All the modeled atmospheric variables in the free atmosphere have been bilinearly interpolated to a horizontal resolution of $2.5^{\circ} \times 2.5^{\circ}$.

According to previous studies, the biases among the different members of the IPSL-CM6A-LR model can be attributed to the internal climate variability (Deser et al. 2012; Deser et al. 2014; Deser et al. 2016). Thus, the model's internal climate variability can be extracted as the inter-member spread from the multimember mean. To explore the relationships between the inter-member spread of the trends in two variables, the linear regressions were used in the present paper. Following previous studies (Deser et al. 
2014; Hu et al. 2019), empirical orthogonal function (EOF) analysis was applied to extract the leading patterns of the internal climate variability. The vertical component of stationary wave activity flux (SWAF) derived by Plumb (1985) was applied to analyze the behavior of stationary wave activity in the atmosphere. The two-tailed Student's $t$-test was used to evaluate the statistical significance of regression and correlation analysis. Due to the limited number of cases, the two-tailed nonparametric Monte Carlo bootstrap significance test was utilized in the composite analysis. Detailed descriptions of the two-tailed nonparametric Monte Carlo bootstrap significance test are provided in Ding et al. (2018).

\section{Results}

\subsection{Trend analysis}

Figure 1a displays the observed winter SAT trend during 1991-2014. The period 1991-2014 was chosen because the winter SAT trend pattern during this time exhibits a strongly pronounced "warm Arctic-cold Eurasia" pattern. The results obtained in this study were unaffected by altering the period forwards by several years. As shown in Fig. 1a, significant warming anomalies can be observed over the Arctic, especially over the Barents-Kara Seas $\left(70^{\circ}-85^{\circ} \mathrm{N}, 15^{\circ}-70 \mathrm{E}^{\circ}\right)$. Meanwhile, an apparent cooling trend can be seen over central Eurasia $\left(40^{\circ}-60^{\circ} \mathrm{N}, 50^{\circ}-130^{\circ} \mathrm{E}\right)$ in boreal winter (Fig. 1a), which is consistent with previous studies (Wu et al. 2011; Cohen et al. 2013; Wang and Chen 2013; Wang et al. 2020e). The winter SAT trend shown in Fig. 1a was determined by a combination of external forcing and internal climate variability. Following previous studies (Deser et al. 2012; Kang et al. 2013; Deser et al. 2014), the trends due to external forcing can be calculated as the average of trends in the 31 ensemble members. Figure $1 \mathrm{~b}$ displays the winter SAT trends during 1991-2014 generated by external forcing, which are defined as the average of trends in the IPSL-CM6A-LR 31 ensemble members. The ensemble-mean winter SAT trend (Fig. 1b) shows robust warming trend over the Arctic Ocean and American and Eurasian land areas. The forced response is not uniform, with higher warming rates over the Arctic, especially over the BarentsKara Seas region (Fig. 1b). However, the magnitude of the ensemble-mean SAT trend over the BarentsKara Seas is smaller than that in the observational data. Thus, it is speculated that the trend component of winter SAT arising from internal variability may exacerbate the forced response over the Barents-Kara Seas and mask the forced response over inland northern East Asia.

The relative contributions of external forcing and internal climate variability to the winter SAT trend can be estimated quantitatively by calculating the signal-to-noise ratio (SNR). The SNR is calculated as the ratio of the ensemble-mean winter SAT trends to the standard deviation of the deviation from the ensemble mean trend among the 31 ensemble members (Deser et al. 2012). Figures 1c and d display the spatial distributions of the inter-member standard deviations and SNR for the winter SAT trends during 1991-2014, respectively. Large inter-member standard deviations of the winter SAT (more than 1.0) can be observed over the Barents-Kara Seas and over the mid and high latitudes of the Eurasian continent (Fig. 1c). The SNRs of winter SAT trends are larger than those over the Pacific sector of the Arctic and the Russian Far East (Fig. 1d). In contrast, low SNRs (values lower than one) of winter SAT trends appear over the Atlantic sector of the Arctic, especially over the Barents-Kara Seas and over the mid and high 
latitudes of the Eurasian continent (Fig. 1d). Thus, the winter SAT trends over the Barents-Kara Seas and central Eurasia are both strongly influenced by internal climate variability.

Figures 2a and b display the normalized winter SAT trends during 1991-2014 averaged over the Barents-Kara Seas and central Eurasia in 31 IPSL-CM6A-LR ensemble members, respectively. As expected, there are considerable inter-member spreads in the winter SAT trends over the Barents-Kara Seas and central Eurasia across the 31 ensemble members. This implies that internal climate variability can exert a larger impact on the winter SAT trends over the Barents-Kara Seas and central Eurasia. Figures $2 \mathrm{c}$ and d display the regressed winter SAT trends during 1991-2014 with respect to the normalized winter SAT trends averaged over the Barents-Kara Seas and central Eurasia, respectively. Note that the domain-average winter SAT trends over central Eurasia is multiplied by -1 for a clear comparison. Generally, a strong warming trend over the Barents-Kara Seas corresponds to positive winter SAT trends over most parts of the Arctic and across the Arctic coastline (Fig. 2c). Associated with the warming trend over the Barents-Kara Seas, a cooling trend can be observed over the Eurasian midlatitudes (Fig. 2c). However, the magnitude of the cooling signal is much smaller than that of the warming signal. Furthermore, the main body of the cooling signal is not located over central Eurasia. Associated with the cooling trend over central Eurasia, uniform negative winter SAT trends can be observed over the entire land area of northern Eurasia (Fig. 2d). Actually, the correlation coefficient between the winter SAT trends during 1991-2014 averaged over the Barents-Kara Seas and central Eurasia is only 0.02 among the 31 ensemble members. Therefore, the presumption that the observed cooling trend over central Eurasia is caused by Arctic warming may not be supported in our study. Furthermore, it seems that the warming trend over the Barents-Kara Seas and cooling trend over central Eurasia are not caused by a common internal driver.

\subsection{Physical processes for internally driven Arctic SAT trends}

The above analysis has indicated that the observed winter SAT trends over the Barents-Kara Seas and central Eurasia during 1991-2014 were strongly influenced by internal climate variability. In this part, we examine the physical processes responsible for the internal variability of the winter SAT trends over the Barents-Kara Seas. Previous studies have reported that the interdecadal increase in SAT over the Barents-Kara Seas can be explained by an interdecadal increase in wintertime water vapor and accompanying enhancement of downward longwave radiation (DLR) (Wang et al. 2020b). The intermember spread of winter SAT trends over the Barents-Kara Seas may be driven by the same mechanism. To investigate this hypothesis, we display the regressed trend in winter DLR and total column water (TCW) with respect to the normalized winter SAT trends averaged over the Barents-Kara Seas. Inspection of the winter DLR trends indicates that the inter-member spread of the winter SAT trends over the Barents-Kara Seas is closely associated with the variation there of the winter DLR trends (Fig. 3a). Being excellent emitters of DLR, the regressed winter TCW trends patterns match well with those of the winter DLR trends (Fig. 3b). Therefore, the internal variability of the winter SAT trends over the Barents-Kara Seas can also be driven by the internally driven TCW trends and associated change in the DLR trends. 
Figures $3 \mathrm{c}$ and d display scatterplots of the normalized winter SAT and TCW trends averaged against the normalized winter DLR trend averaged over the Barents-Kara Seas in the 31 members of the IPSL-CM6ALR model. A strong linear relationship exists between the normalized winter SAT and DLR trends averaged over the Barents-Kara Seas, with a correlation of 0.996 (Fig. 3c). Furthermore, the inter-member spread of the winter DLR trends is closely related to that of the TCW trends, with a correlation of 0.975 (Fig. 3d). The above analysis indicates that the inter-member spread of the winter SAT trends over the Barents-Kara Seas is also regulated by the same mechanism as that of the observed interdecadal variability. Therefore, we should be able to shed light on the physical processes accounting for the change in the winter TCW trends over the Barents-Kara Seas to reveal the internal drivers there of the winter SAT trends.

It is known that an increase in TCW may be caused by local processes (such as increased evaporation) or result from increased moisture transport from other regions. Wang et al. (2020b) reported that the stationary component of moisture flux convergence has contributed positively to the interdecadal increase in TCW over the Barents-Kara Seas region since the mid-2000s. Therefore, the regressed trends of wintertime evaporation and stationary moisture flux convergence with respect to domain-averaged SAT trends over the Barents-Kara Seas are displayed in Figs. 4a and b. Corresponding to the warming trend over the Barents-Kara Seas, an increase in evaporation and moisture flux convergence can be observed over the same region (Figs. $4 \mathrm{a}$ and b). We further display scatterplots of the normalized domain-averaged TCW trends against the normalized domain-averaged evaporation and moisture flux convergence trends over the Barents-Kara Seas in Figs. 4c and d. It is clear that the inter-member spread of the winter TCW trends over the Barents-Kara Seas have significant positive relations with that of the trends of evaporation and moisture flux convergence (Figs. 4c and d). However, the correlation coefficient between the TCW and evaporation trends (0.927) is larger than the correlation coefficient between the TCW and moisture flux convergence trends (0.434). Measured by correlation coefficients, the variation of the winter TCW trends over the Barents-Kara Seas is mainly driven by the local evaporation process. The anomalous moisture flux convergence induced by internal atmospheric variability plays only a secondary role.

\subsection{Internal drivers of a warm Arctic and cold Eurasia}

The above results indicate that the internally driven TCW trends over the Barents-Kara Seas arise mainly from the local evaporation process. Considering the important role of local SST in influencing evaporation over the ocean, it is assumed that the change in SST may be the most important internal driver for the warming trend over the Barents-Kara Seas. The relation between the variation of the intermember spread of the trends of winter SAT and SST is examined in the following. Figure 5a displays the regressed winter SST trends with respect to normalized winter SAT trends averaged over the BarentsKara Seas. As shown in Fig. 5a, significant positive SST trends can be observed over the Barents-Kara Seas, implying an important role played by local SST change in driving the increase in SAT over the Barents-Kara Seas. As shown in Fig. 5b, a strong linear relationship exists between the SST and SAT 
trends, with a correlation of 0.933 . Therefore, it is possible that local SST change over the Barents-Kara Seas plays the central role in driving the inter-member spread of the winter SAT trends.

Previous studies have reported the importance of variations in sea ice or SST over the Barents-Kara Seas in influencing atmospheric circulation (Inoue et al. 2012; Mori et al. 2014; Wang et al. 2020d). Figure 6 displays the regressed trends of winter SAT, 500-hPa geopotential height (Z500), 300-hPa zonal wind (U300) and sea level pressure (SLP) with respect to normalized winter SST tends averaged over the Barents-Kara Seas. As we can see in Fig. 6a, an increase in SST corresponds to warming anomalies over the Arctic and along the Siberian coast, which implies a weakened mid-latitude and Arctic thermal contrast. Consistent with the thermal wind relation, a decrease in U300 can be observed over northern Eurasia and an increase in U300 is apparent over the northern Barents-Kara Seas (Fig. 6b). According to Wang et al. (2020e), the weak thermal contrast and decrease in U300 over northern Eurasia can lead to weak synoptic-scale eddy activity there. Furthermore, the negative anomalies of synoptic-scale eddy activity can drive an anomalous anticyclone to its south and anomalous anticyclone to its north (Lau 1988; Cai et al. 2007). Thus, an anomalous ridge can be found to the south of the main body of negative U300 anomalies and anomalous cyclone located to its south (Fig. 6c). The anomalous ridge around the Ural Mountains can be caused by an enhanced frequency of Urals blocking (Wang and Chen 2013). According to some studies, the warming trend over the Barents-Kara Seas can provide a favorable condition for enhancement of Urals blocking activity (Mori et al. 2014; Luo et al. 2017; Yao et al. 2017). In the low troposphere, apart from the positive SLP trend over the land areas of Siberia, a decrease in the SLP trends can be observed over the Arctic (Fig. 6d). The change in the winter SLP trends may be induced by the change in the tracks of cyclones. According to previous studies, weaker (stronger) upper-level zonal wind may hinder (facilitate) the eastward propagation of synoptic eddies from this region (Wallace et al. 1988; Chang and Yu 1999; Wang et al. 2020a). The relevant change in U300 corresponds to a northward shift in the cyclone tracks, which means more (fewer) cyclones travel across the Arctic (Siberian coast). This is consistent with the findings of Inoue et al. (2012), who suggested that sea-ice loss and Arctic warming can increase the SLP along the Siberian coast and decrease the SLP over the Arctic through controlling the tracks of cyclones.

Previous studies have indicated that the internally driven SAT trends over Eurasia are mainly caused by internal atmospheric circulation variability (Sun et al. 2016; Wang et al. 2018). Figure 7a displays the regressed winter SLP trends with respect to the normalized domain-averaged SAT trends over central Eurasia. When the cooling trend over central Eurasia occurs, an anomalous anticyclone can be observed over the Arctic and an anomalous cyclone can be observed over East Asia and the North Pacific (Figs. 7a and $b$ ). The associated atmospheric circulation anomalies are very different from those with respect to the domain-average SST trend over the Barents-Kara Seas, implying a negligible role of a warming Arctic in driving a cold Eurasia. The ensemble trend regressions in SLP and Z500 resemble those associated with the negative phase of the AO (Thompson and Wallace 2001; Wang and Chen 2013), implying that a cooling central Eurasia arises mainly from a negative $\mathrm{AO}$ trend. The internally generated $\mathrm{AO}$-like atmospheric circulation pattern can be extracted though EOF analysis. Specifically, EOF analysis was performed on the ensemble SLP trends in the domain of Eurasia $\left(30^{\circ}-90^{\circ} \mathrm{N}, 0^{\circ}-180^{\circ} \mathrm{E}\right)$ among the 31 
ensemble members. The first EOF mode (EOF1) of the internally generated winter SLP trends over Eurasia explains about $49.0 \%$ of the winter SLP trends among the 31 ensemble members and can be well separated from the others according to the criterion of North et al. (1982). Figures 7c and d display regression maps of the trends of the winter SLP and SAT upon the first leading principal component (PC1). The EOF1 mode bears a close resemblance to the regressed SLP trend pattern with respect to the domain-average winter SAT trend over central Eurasia (Figs. 7a and c). Furthermore, the spatial structure of the regressed trends of winter SAT upon PC1 is similar to that associated with a cold central Eurasia (Figs. $2 \mathrm{~d}$ and 7d). The correlation coefficient between PC1 and the domain-average SAT trend over Eurasia is as high as 0.815 , and is significant at the $99 \%$ confidence level according to the two-tailed Student's $t$-test. These results suggest that the EOF1 mode plays the dominant role in contributing to the decrease in SAT over central Eurasia.

\subsection{Causes of the observed trend pattern of SAT and circulation anomalies}

According to above analysis, the observed "warm Arctic-cold Eurasia" trend pattern may be caused by the coincidence of warming tends of SST over the Barents-Kara Seas and a positive phase of the EOF1 mode. To test this suggestion, ensemble members are selected when both the normalized SST trends averaged over the Barents-Kara Seas and PC1 exceed a criterion of $0.5 \sigma$ to construct a "combined composite". According to this criterion, five cases were selected from all members. Figure 8 displays the observed trends of winter SAT, SLP, and Z500 during 1991-2014, along with the composite trends of winter SAT, SLP and Z500, for the five selected cases. As shown in Figs. 8a-c, accompanying the emergence of the "warm Arctic-cold Eurasia" trend pattern in wintertime temperatures, a significant change in the atmospheric circulation can be observed over the northern Eurasian continent. Specifically, a significant increase in wintertime SLP can be observed over the northern Eurasian continent (Fig. 8b), which implies amplification of the Siberian high. For wintertime Z500, its trend pattern displays a Rossbywave-like pattern over northern Eurasia, with positive Z500 anomalies over the Barents-Kara Seas and negative Z500 anomalies above East Asia (Fig. 8c). The linear combination of the warming trend of SST over the Barents-Kara Seas and positive PC1 can reproduce well the observed "warm Arctic-cold Eurasia" trend pattern and associated atmospheric circulation change over the land areas of Eurasia. Thus, the observed warming trend over the Barents-Kara Seas and cooling trend over central Eurasia arise partly from the coincidence of the warming trend in SST over the Barents-Kara Seas and declining trend in the wintertime AO index. The internally generated SST trend over the Barents-Kara Seas may exert a modulating impact on the AO-related anomaly patterns. Specifically, the positive SLP trends over the Arctic with respect to PC1 are offset by the SST-forced SLP anomalies. It should be noted that the linear combination cannot reproduce the SAT change and atmospheric circulation change over the North Pacific, implying that other physical processes may account for the climate change over the North Pacific.

According to Wang et al. (2020e), the anomalous ridge around the Ural Mountains and trough over the Far East correspond to an enhancement of the enhanced stationary wave amplitude and an increase in 
the vertical component of SWAF. Figure 9 displays the trends in the vertical component of SWAF at 500 $\mathrm{hPa}$ for the observation and five selected ensemble members. In the observation, a significant increase in the vertical component of SWAF can be seen in the northern part of Eurasia, which is consistent with the

findings of Wang et al. (2020e). Furthermore, the enhancement of stationary wave activity in the northern part of Eurasia can be reproduced in the five selected cases. Thus, although it is suggested that the warming over the Barents-Kara Seas provides a favorable condition for enhancement of the stationary wave activity in the northern part of Eurasia (Wang et al. 2020e), it cannot account fully for the change in the stationary wave activity.

\section{Summary And Discussion}

In this paper we have investigated the role of internal variability in the formation of the opposite trends in winter SAT over the Barents-Kara Seas and central Eurasia during 1991-2014 through analysis of large ensembles of fully coupled climate model simulations with historical radiative forcing. Measured by the standard deviation of the winter SAT trends, the trends in winter SAT over the Barents-Kara Seas and central Eurasia display large inter-member diversity across all the ensemble members. This suggests that internal climate variability is vital to the recent observed trends in wintertime SAT over the Barents-Kara Seas and central Eurasia.

Our study indicates that the inter-member variations of the winter SAT trends over the Barents-Kara Seas are mainly caused by the change in local SST. An increase in SST over the Barents-Kara Seas can lead to enhancement of TCW and DLR through affecting local evaporation. The warming trend over the Barents-Kara Seas can also induce an anomalous anticyclone over northern Eurasia, which in turn can contribute positively to the warming anomalies over the Barents-Kara Seas through its impacting on moisture transport. However, stationary moisture flux convergence is suggested to play only a secondary role in inducing the warming trend over the Barents-Kara Seas. The inter-member variations of the trend in winter SAT over central Eurasia are closely associated with the internally driven AO-like atmospheric circulation. In other words, the cooling trend that occurred over central Eurasia during 1991-2014 was mainly induced by a decline in the winter $A O$ index for this period. Lastly, we demonstrate that the recent "warm Arctic-cold Eurasia" trend pattern and associated changes in atmospheric circulation over northern Eurasia can be attributed to the coincidence of the warming trend in SST over the Barents-Kara Seas and the declining trend in the winter $\mathrm{AO}$ index over the same period.

Previous studies have also emphasized the role played by an increase in water vapor in enhancing wintertime DLR and increasing wintertime SAT over the Arctic on multiple time scales (Park et al. 2015; Gong et al. 2017; Wang et al. 2020b). However, some studies have reported that increases in water vapor over the Arctic are mainly driven by the horizontal atmospheric water flux into the Arctic and not by evaporation from the Arctic Ocean (Park et al. 2015; Gong et al. 2017). It should be noted that these studies were based on the assumption that the same process that drives the intraseasonal variability in SAT also plays a significant role in contributing to the long-term SAT trend. However, since the ocean 
signal (such as evaporation over the Arctic Ocean) operates over a much longer time scale, its impact on the Arctic SAT trend cannot be fully evaluated using their intraseasonal link.

Previous studies have indicated that the significant decrease in the winter AO index since the late 1980s has favored anomalously cold temperatures over northern Eurasia (Cohen et al. 2012b). Some studies indicate that sea-ice loss over the Barents-Kara Seas can decrease the SAT over Eurasia through its impact on atmospheric circulation anomalies on the interannual time scale (Mori et al. 2014; Wang et al. 2020d). However, according to our findings, the cooling trend over central Eurasia is not the immediate response triggered by the increase in SST over the Barents-Kara Seas. Some previous studies have emphasized the role of Arctic sea-ice loss during late summer to fall in exciting the negative AO-like atmospheric circulation pattern and cold continents in the following winter (Honda et al. 2009; Nakamura 2015; Zhang et al. 2018). However, as some studies indicate, the observed covariability between the Arctic sea ice during late summer to fall and the winter extratropical atmospheric circulation does not necessarily imply causality (Wang et al. 2020c; Warner et al. 2020). Thus, additional research is necessary to elucidate the role of Arctic sea-ice loss and Arctic warming in causing the cold continents.

\section{Declarations}

\section{Conflict of interests}

The authors declare no potential conflict of interest.

\section{Acknowledgements}

This study was supported jointly by the National Natural Science Foundation of China (Grants 41721004 and 41961144025), the Chinese Academy of Sciences Key Research Program of Frontier Sciences (QYZDY-SSW-DQC024), and the Jiangsu Collaborative Innovation Center for Climate Change.

\section{References}

Boucher 0 et al. (2020) Presentation and Evaluation of the IPSL-CM6A-LR Climate Model. J ADV MODEL EARTH SY 12:e2019MS002010. https://doi.org/10.1029/2019ms002010

Cai M, Yang S, Dool HMVD, Kousky VE (2007) Dynamical implications of the orientation of atmospheric eddies: a local energetics perspective. Tellus A 59:127-140. https://doi.org/10.1111/j.1600-

0870.2006.00213.x

Chang EKM, Yu DB (1999) Characteristics of Wave Packets in the Upper Troposphere. Part I: Northern Hemisphere Winter. J Atmos Sci 42:1708-1728 
Cohen J, Jones J, Furtado J, Tziperman E (2013) Warm Arctic, Cold Continents: A Common Pattern Related to Arctic Sea Ice Melt, Snow Advance, and Extreme Winter Weather. Oceanography 26. https://doi.org/10.5670/oceanog.2013.70

Cohen J et al. (2014) Recent Arctic amplification and extreme mid-latitude weather. Nat Geosci 7:627-637. https://doi.org/10.1038/ngeo2234

Cohen JL, Furtado JC, Barlow M, Alexeev VA, Cherry JE (2012a) Asymmetric seasonal temperature trends. Geophys Res Lett 39:54-62

Cohen JL, Furtado JC, Barlow MA, Alexeev VA, Cherry JE (2012b) Arctic warming, increasing snow cover and widespread boreal winter cooling. Environ Res Lett 7:014007. https://doi.org/10.1088/1748$9326 / 7 / 1 / 014007$

Dee DP et al. (2011) The ERA-Interim reanalysis: configuration and performance of the data assimilation system. Quarterly Q J R Meteorol Soc 137:553-597

Deser C, Knutti R, Solomon S, Phillips AS (2012) Communication of the role of natural variability in future North American climate. Nat Clim Change 2:775-779. https://doi.org/10.1038/nclimate1562

Deser C, Phillips AS, Alexander MA, Smoliak BV (2014) Projecting North American Climate over the Next 50 Years: Uncertainty due to Internal Variability*. J Clim 27:2271-2296. https://doi.org/10.1175/jcli-d-1300451.1

Deser C, Terray L, Phillips AS (2016) Forced and Internal Components of Winter Air Temperature Trends over North America during the past 50 Years: Mechanisms and Implications. J Clim 29:2237-2258. https://doi.org/10.1175/jcli-d-15-0304.1

Ding Q et al. (2019) Fingerprints of internal drivers of Arctic sea ice loss in observations and model simulations. Nat Geosci 12:28-33. https://doi.org/10.1038/s41561-018-0256-8

Ding S, Chen W, Graf H, Guo Y, Nath D (2018) Distinct winter patterns of tropical Pacific convection anomaly and the associated extratropical wave trains in the Northern Hemisphere. Clim Dyn 51:20032022

Eyring V, Bony S, Meehl GA, Senior CA, Stevens B, Stouffer RJ, Taylor KE (2016) Overview of the Coupled Model Intercomparison Project Phase 6 (CMIP6) experimental design and organization. Geosci Model Dev 9:1937-1958. https://doi.org/10.5194/gmd-9-1937-2016

Feng C, Wu B (2015) Enhancement of Winter Arctic Warming by the Siberian High over the Past Decade. Atmos Ocean Sci Lett 8:257-263

Gong T, Feldstein S, Lee S (2017) The Role of Downward Infrared Radiation in the Recent Arctic Winter Warming Trend. J Clim 30:4937-4949. https://doi.org/10.1175/jcli-d-16-0180.1 
Honda M, Inoue J, Yamane S (2009) Influence of low Arctic sea-ice minima on anomalously cold Eurasian winters. Geophys Res Lett 36. https://doi.org/10.1029/2008gl037079

Hu K, Huang G, Xie S-P (2019) Assessing the internal variability in multi-decadal trends of summer surface air temperature over East Asia with a large ensemble of GCM simulations. Clim Dyn 52:62296242. https://doi.org/10.1007/s00382-018-4503-x

Inoue J, Hori ME, Takaya K (2012) The Role of Barents Sea Ice in the Wintertime Cyclone Track and Emergence of a Warm-Arctic Cold-Siberian Anomaly. J Clim 25:2561-2568. https://doi.org/10.1175/jcli-d$11-00449.1$

Jeong J-H, Ou T, Linderholm HW, Kim B-M, Kim S-J, Kug J-S, Chen D (2011) Recent recovery of the Siberian High intensity. J Geophys Res Atmos 116: D23102. https://doi.org/10.1029/2011jd015904

Johannessen OM et al. (2004) Arctic climate change - observed and modeled temperature and sea ice. Tellus 56:328-341

Kang SM, Deser C, Polvani LM (2013) Uncertainty in Climate Change Projections of the Hadley Circulation: The Role of Internal Variability. J Clim 26:7541-7554. https://doi.org/10.1175/jcli-d-1200788.1

Kug J-S, Jeong J-H, Jang Y-S, Kim B-M, Folland CK, Min S-K, Son S-W (2015) Two distinct influences of Arctic warming on cold winters over North America and East Asia. Nat Geosci 8:759-762.

https://doi.org/10.1038/ngeo2517

Lau NC (1988) Variability of the Observed Midlatitude Storm Tracks in Relation to Low-Frequency Changes in the Circulation Pattern. J Atmos Sci 45:2718-2743

Liu J, Curry JA, Wang H, Song M, Horton RM (2012) Impact of declining Arctic sea ice on winter snowfall. Proc Natl Acad Sci USA 109:4074-4079. https://doi.org/10.1073/pnas.1114910109

Luo D, Yao Y, Dai A, Simmonds I, Zhong L (2017) Increased Quasi Stationarity and Persistence of Winter Ural Blocking and Eurasian Extreme Cold Events in Response to Arctic Warming. Part II: A Theoretical Explanation. J Clim 30:3569-3587. https://doi.org/10.1175/jcli-d-16-0262.1

Mori M, Watanabe M, Shiogama H, Inoue J, Kimoto M (2014) Robust Arctic sea-ice influence on the frequent Eurasian cold winters in past decades. Nat Geosci 7:869-873. https://doi.org/10.1038/ngeo2277

Nakamura T, K. Yamazaki,K.Iwamoto, M. Honda, Y. Miyoshi, Y. Ogawa, and J. Ukita (2015) A negative phase shift of the winter AO/NAO due to the recent Arctic sea-ice reduction in late autumn. J Geophys Res Atmos 120: 3209-3227 https://doi.org/10.1002/

North GR, Bell TL, Cahalan RF, Moeng FJ (1982) Sampling Errors in the Estimation of Empirical Orthogonal Functions. Mon Weather Rev 110:699-706. https://doi.org/10.1175/1520- 
Overland JE, Wood KR, Wang M (2010) Warm Arctic-cold continents: climate impacts of the newly open Arctic Sea. Polar Res, 30: 15787

Park DSR, Lee S, Feldstein SB (2015) Attribution of the Recent Winter Sea Ice Decline over the Atlantic Sector of the Arctic Ocean*. J Clim 28:4027-4033

Plumb RA (1985) On the Three-Dimensional Propagation of Stationary Waves. J Atmos Sci 42:217-229

Polyakov IV et al. (2002) Observationally based assessment of polar amplification of global warming. Geophys Res Lett 29:25-21-25-24. https://doi.org/10.1029/2001gl011111

Screen JA, Simmonds I (2010a) The central role of diminishing sea ice in recent Arctic temperature amplification. Nature 464:1334-1337. https://doi.org/10.1038/nature09051

Screen JA, Simmonds I (2010b) Increasing fall-winter energy loss from the Arctic Ocean and its role in Arctic temperature amplification. Geophys Res Lett 37: L16797. https://doi.org/10.1029/2010gl044136

Serreze MC, Barrett AP, Stroeve JC, Kindig DN (2008) The emergence of surface-based Arctic amplification. The Cryosphere 3:11-19

Serreze MC, Barry RG (2011) Processes and impacts of Arctic amplification: A research synthesis. Global Planet Change 77:85-96. https://doi.org/10.1016/j.gloplacha.2011.03.004

Sun L, Perlwitz J, Hoerling M (2016) What caused the recent "Warm Arctic, Cold Continents" trend pattern in winter temperatures? Geophys Res Lett 43:5345-5352. https://doi.org/10.1002/2016gl069024

Tang Q, Zhang X, Yang X, Francis JA (2013) Cold winter extremes in northern continents linked to Arctic sea ice loss. Environ Res Lett 8:014036. https://doi.org/10.1088/1748-9326/8/1/014036

Thompson DWJ, Wallace JM (2001) Regional climate impacts of the Northern Hemisphere annular mode. Science 293:85-89. https://doi.org/10.1126/science.1058958

Trenberth KE, Fasullo JT, Branstator G, Phillips AS (2014) Seasonal aspects of the recent pause in surface warming. Nat Clim Change 4:911-916. https://doi.org/10.1038/nclimate2341

Wallace JM, Lim G-H, Blackmon ML (1988) Relationship between Cyclone Tracks, Anticyclone Tracks and Baroclinic Waveguides. J Atmos Sci 45:439-462. https://doi.org/10.1175/15200469(1988)045<0439:Rbctat>2.0.Co;2

Wang L, Chen W (2013) The East Asian winter monsoon: re-amplification in the mid-2000s. Chin Sci Bull 59: 430-436. https://doi.org/10.1007/s11434-013-0029-0 
Wang L, Deng A, Huang R (2018) Wintertime internal climate variability over Eurasia in the CESM large ensemble. Clim Dyn 52: 6735-6748

Wang S, Chen W, Chen S, Ding S (2020a) Interdecadal change in the North Atlantic storm track during boreal summer around the mid-2000s: role of the atmospheric internal processes. Clim Dyn 55:19291944. https://doi.org/10.1007/s00382-020-05360-w

Wang S, Chen W, Chen S, Nath D, Wang L (2020b) Anomalous winter moisture transport associated with the recent surface warming over the Barents-Kara seas region since the mid-2000s. Int J Climatol 40:2497-2505. https://doi.org/10.1002/joc.6337

Wang S, Nath D, Chen W (2020c) Nonstationary relationship between sea ice over Kara-Laptev seas during August-September and Ural blocking in the following winter. Int J Climatol https://doi.org/10.1002/joc.6794

Wang S, Nath D, Chen W, Ma T (2020d) CMIP5 model simulations of warm Arctic-cold Eurasia pattern in winter surface air temperature anomalies. Clim Dyn 54:4499-4513. https://doi.org/10.1007/s00382-02005241-2

Wang S, Nath D, Chen W, Wang L (2020e) Changes in winter stationary wave activity during weak midlatitude and Arctic thermal contrast period. Int J Climatol 40:1755-1768. https://doi.org/10.1002/joc.6299

Warner JL, Screen JA, Scaife AA (2020) Links Between Barents-Kara Sea Ice and the Extratropical Atmospheric Circulation Explained by Internal Variability and Tropical Forcing. Geophys Res Lett 47:e2019GL085679. https://doi.org/10.1029/2019gl085679

Wu B, Su J, Zhang R (2011) Effects of autumn-winter Arctic sea ice on winter Siberian High. Chin Sci Bull 56:3220. https://doi.org/10.1007/s11434-011-4696-4

Yao Y, Luo D, Dai A, Simmonds I (2017) Increased Quasi Stationarity and Persistence of Winter Ural Blocking and Eurasian Extreme Cold Events in Response to Arctic Warming. Part I: Insights from Observational Analyses. J Clim 30:3549-3568. https://doi.org/10.1175/jcli-d-16-0261.1

Zhang P, Wu Y, Simpson IR, Smith KL, Zhang X, De B, Callaghan P (2018) A stratospheric pathway linking a colder Siberia to Barents-Kara Sea sea ice loss. Sci Adv 4:eaat6025.

https://doi.org/10.1126/sciadv.aat6025

\section{Figures}



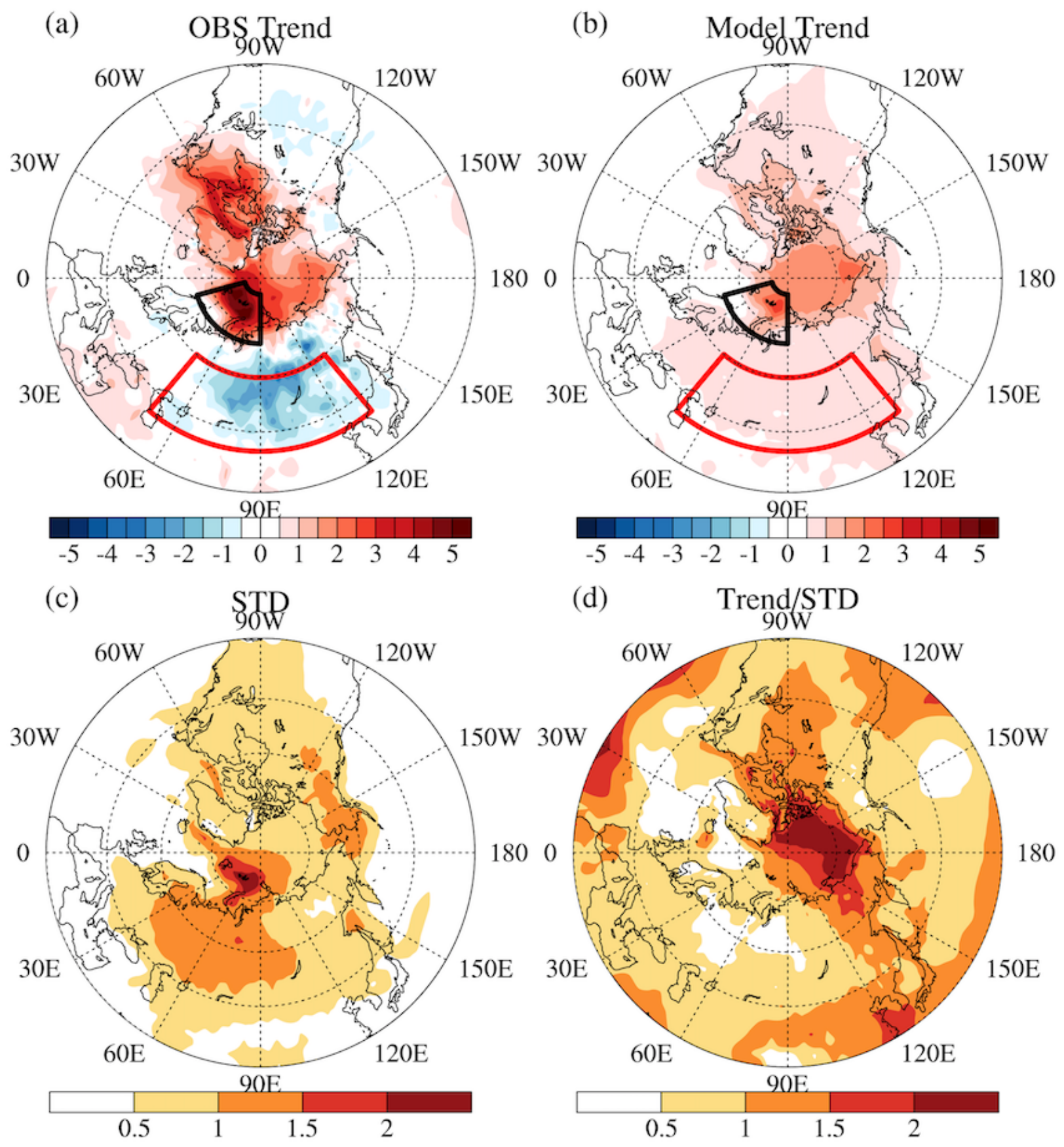

\section{Figure 1}

The (a) observed and (b) ensemble-mean winter SAT trends (K/10 yr) during 1991-2014, (c) the standard deviation of the winter SAT trends, and (d) the ratio of the ensemble mean to the standard deviation of the winter SAT trends among the 31 IPSL-CM6A-LR ensemble members. Note: The designations employed and the presentation of the material on this map do not imply the expression of any opinion whatsoever on the part of Research Square concerning the legal status of any country, territory, city or 
area or of its authorities, or concerning the delimitation of its frontiers or boundaries. This map has been provided by the authors.
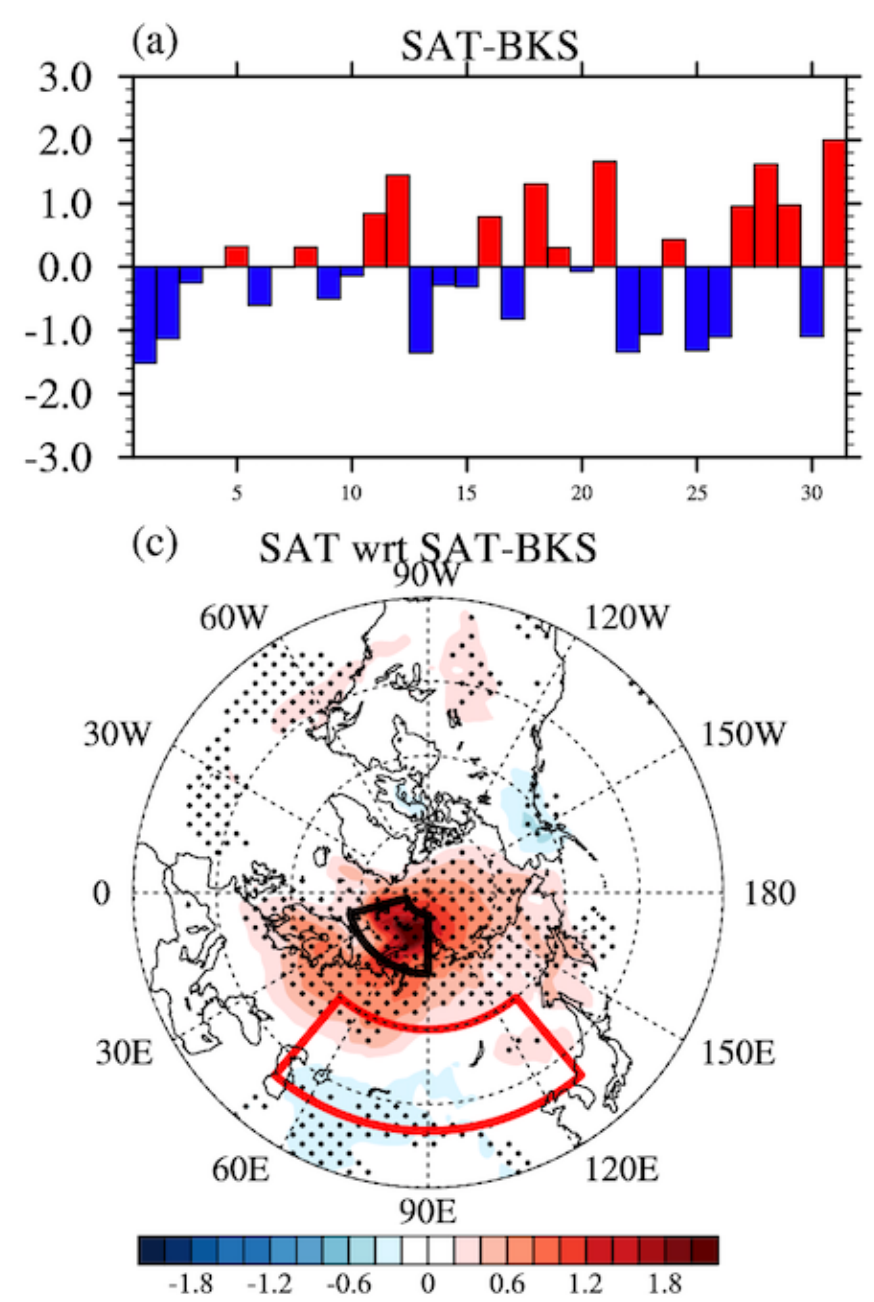
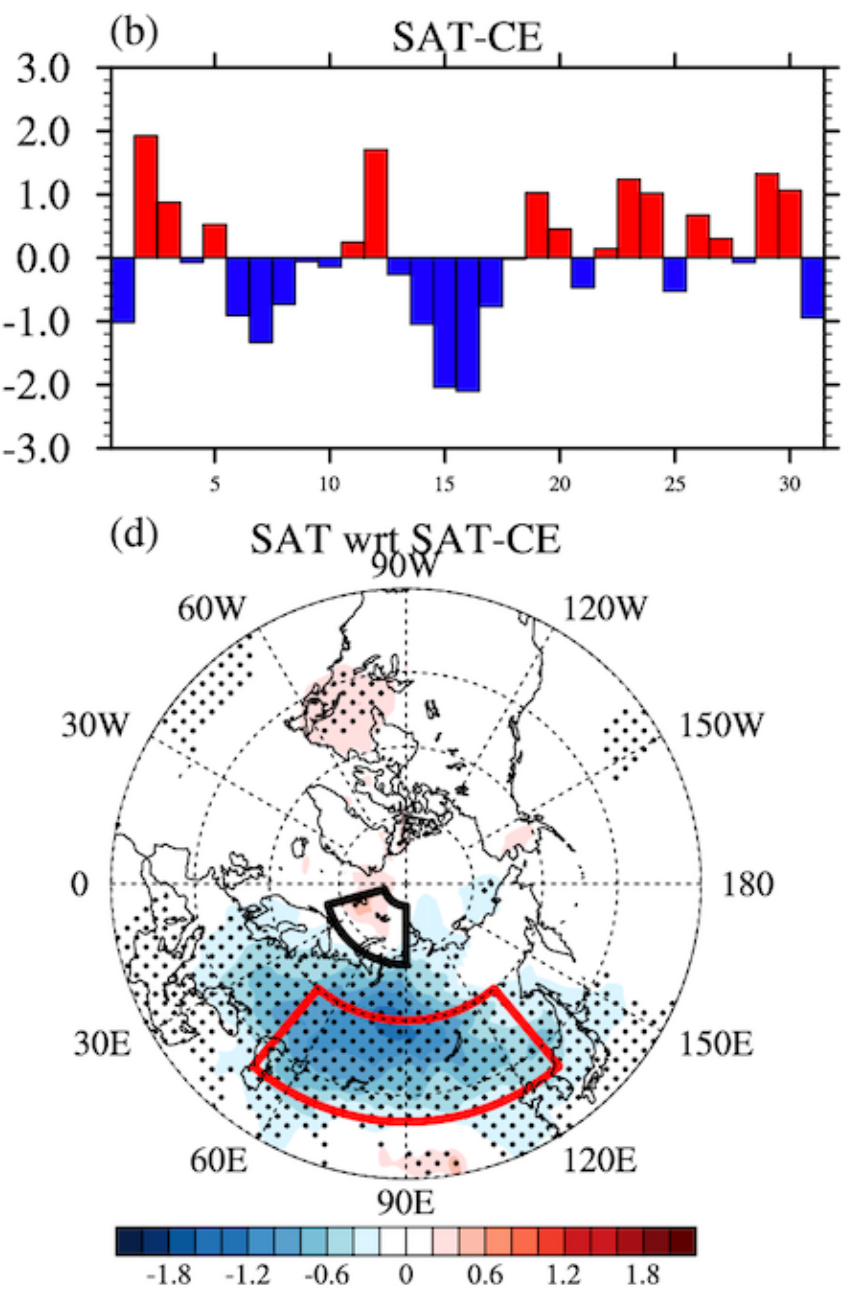

\section{Figure 2}

$(\mathrm{a}, \mathrm{b})$ Normalized winter SAT trends averaged over (a) the Barents-Kara Seas $\left(70^{\circ}-85^{\circ} \mathrm{N}, 15^{\circ}-70 \mathrm{E}^{\circ}\right)$ and (b) central Eurasia $\left(40^{\circ}-60^{\circ} \mathrm{N}, 50^{\circ}-130^{\circ} \mathrm{E}\right)$ in 31 IPSL-CM6A-LR ensemble members. (c, d) Regressions of winter SAT trends $(\mathrm{K} / 10 \mathrm{yr})$ on the normalized winter SAT trend averaged over (c) the Barents-Kara Seas and (d) central Eurasia. Dotted areas denote anomalies that are significant at the $95 \%$ confidence level according to the Student's t-test. Note: The designations employed and the presentation of the material on this map do not imply the expression of any opinion whatsoever on the part of Research Square concerning the legal status of any country, territory, city or area or of its authorities, or concerning the delimitation of its frontiers or boundaries. This map has been provided by the authors. 
(a) DLR wrtSATT-BKS
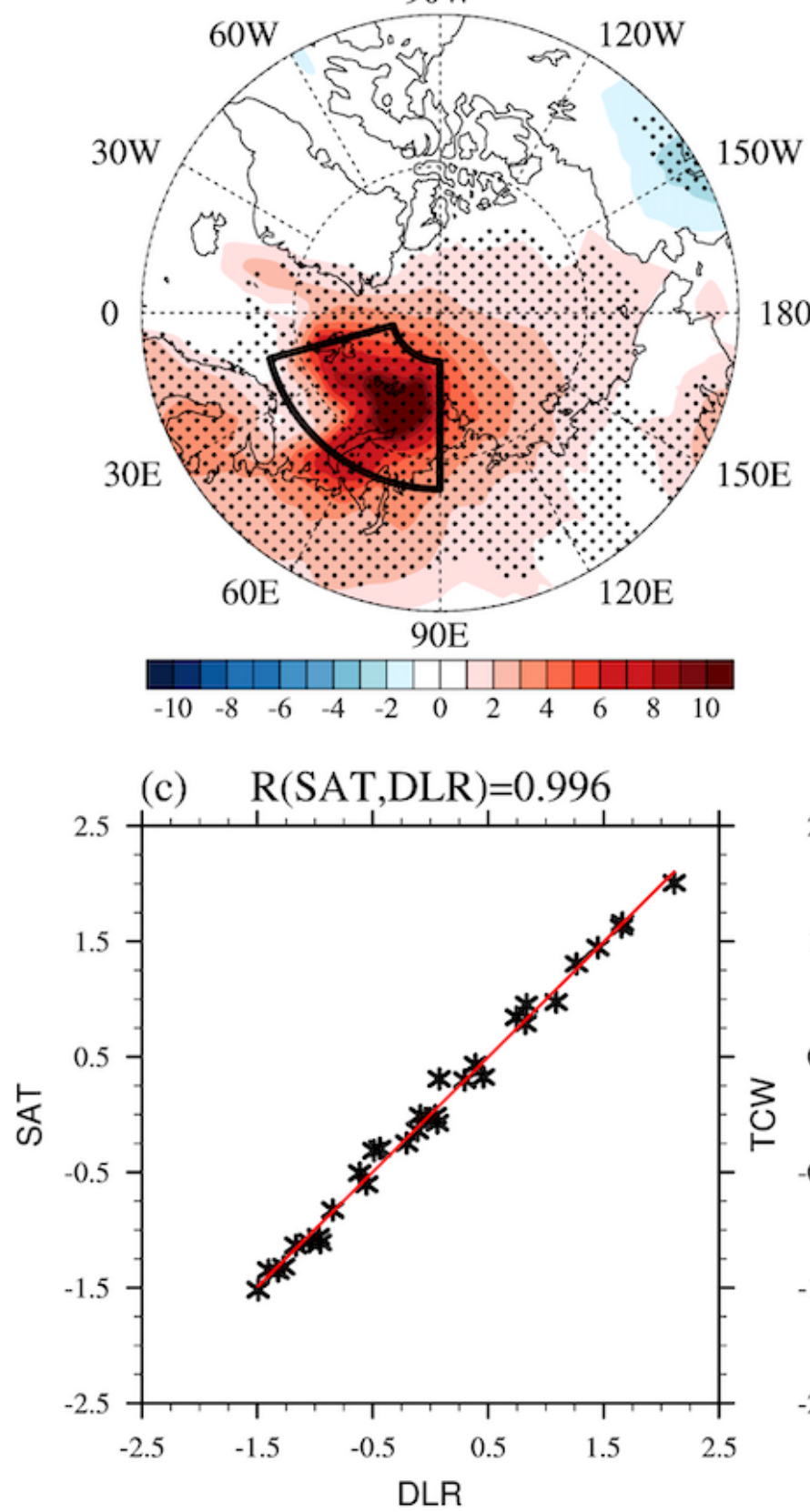

(b) TCW wrt SAT-BKS

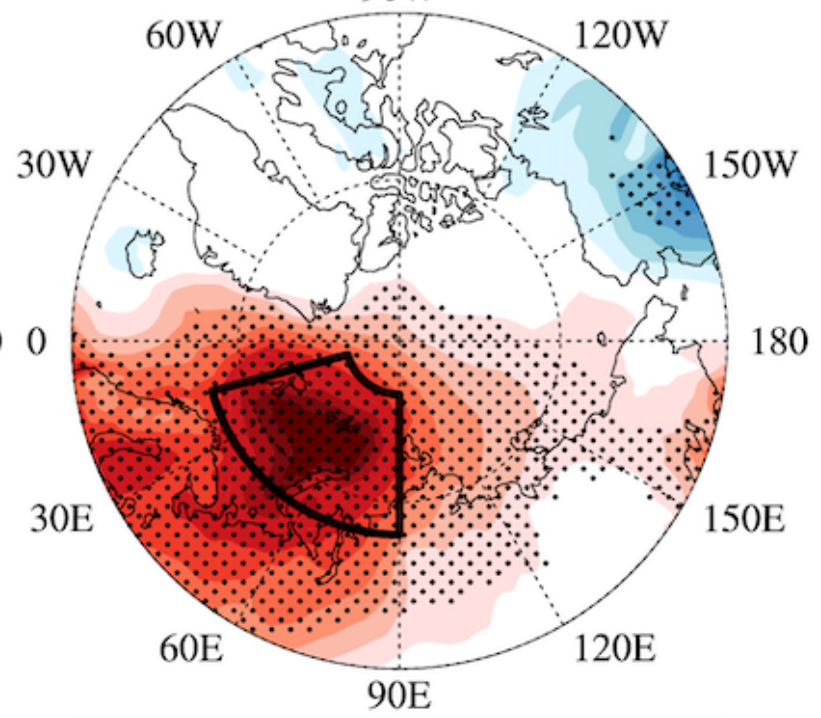

$\begin{array}{lllllllllll}-2.5 & -2 & -1.5 & -1 & -0.5 & 0 & 0.5 & 1 & 1.5 & 2 & 2.5\end{array}$

(d) $\quad \mathrm{R}(\mathrm{DLR}, \mathrm{TCW})=0.975$

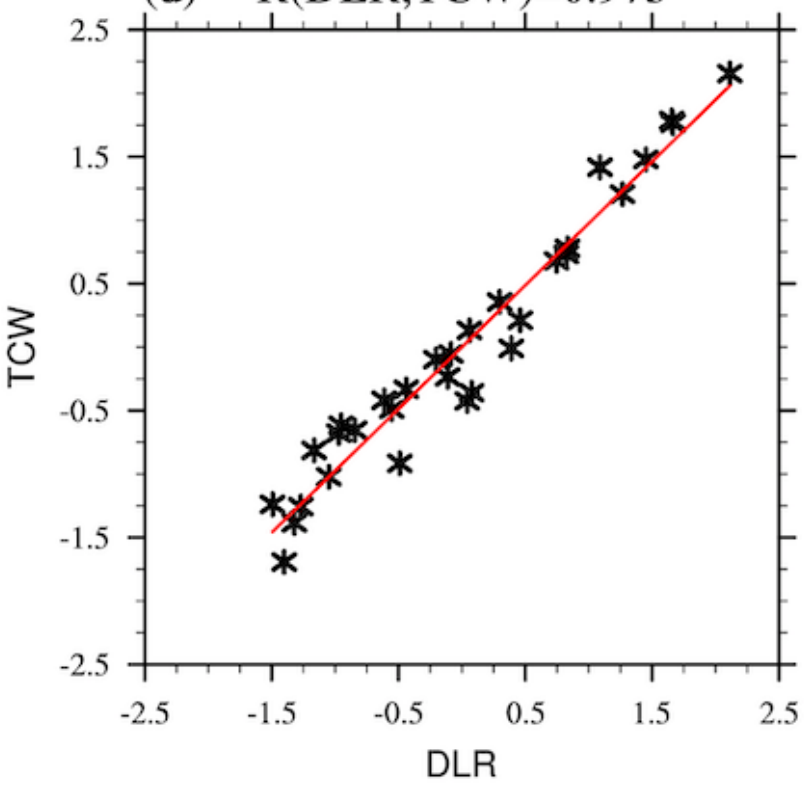

\section{Figure 3}

(a, b) Regressions of the trends of winter (a) DLR (W m-1/10 yr) and (b) TCW (kg/kg/10 yr) on the normalized winter SAT trend averaged over the Barents-Kara Seas. Dotted areas denote anomalies that are significant at the $95 \%$ confidence level according to the Student's t-test. (c, d) Scatterplots of the normalized winter (c) SAT and (d) TCW trend against the normalized winter DLR trend averaged over the Barents-Kara Seas in 31 IPSL-CM6A-LR ensemble members. Note: The designations employed and the 
presentation of the material on this map do not imply the expression of any opinion whatsoever on the part of Research Square concerning the legal status of any country, territory, city or area or of its authorities, or concerning the delimitation of its frontiers or boundaries. This map has been provided by the authors.
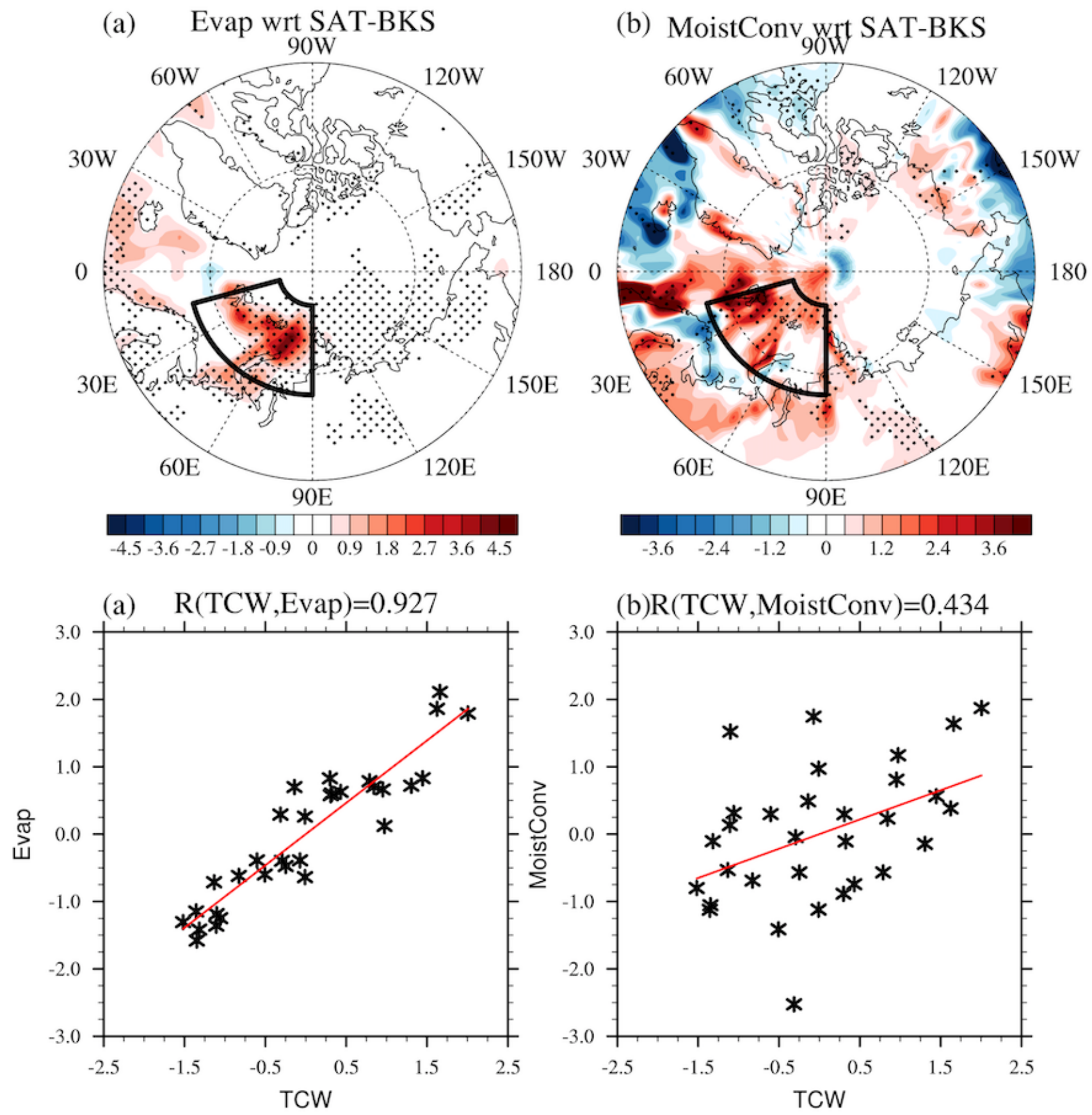

(b)R(TCW,MoistConv $)=0.434$

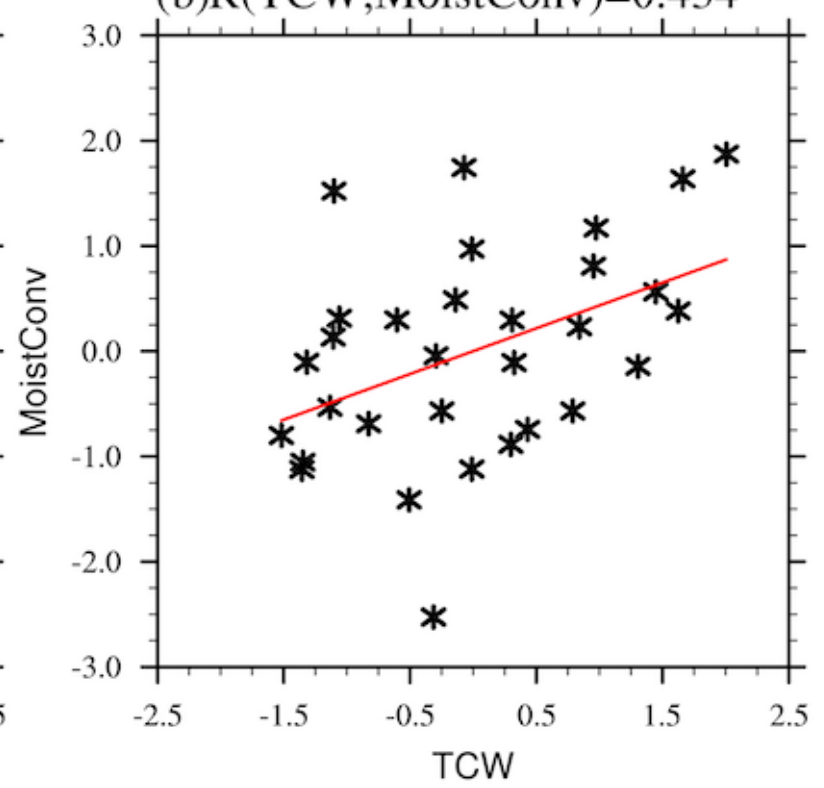

Figure 4 
$(\mathrm{a}, \mathrm{b})$ Regressions of the trends of winter (a) evaporation ( $\mathrm{kg} \mathrm{m}-2 \mathrm{~s}-1 / 10 \mathrm{yr}$ ) and (b) moisture convergence (multiplied by the latent heat of evaporation, $L, W \mathrm{~m}-2 / 10 \mathrm{yr}$ ) on the normalized winter SAT trend averaged over the Barents-Kara Seas. Dotted areas denote anomalies that are significant at the $95 \%$ confidence level according to the Student's t-test. (c, d) Scatterplots of the normalized winter (c) evaporation and (d) moisture convergence trends against the normalized winter TCW trend averaged over the Barents-Kara Seas in 31 IPSL-CM6A-LR ensemble members. Note: The designations employed and the presentation of the material on this map do not imply the expression of any opinion whatsoever on the part of Research Square concerning the legal status of any country, territory, city or area or of its authorities, or concerning the delimitation of its frontiers or boundaries. This map has been provided by the authors. 

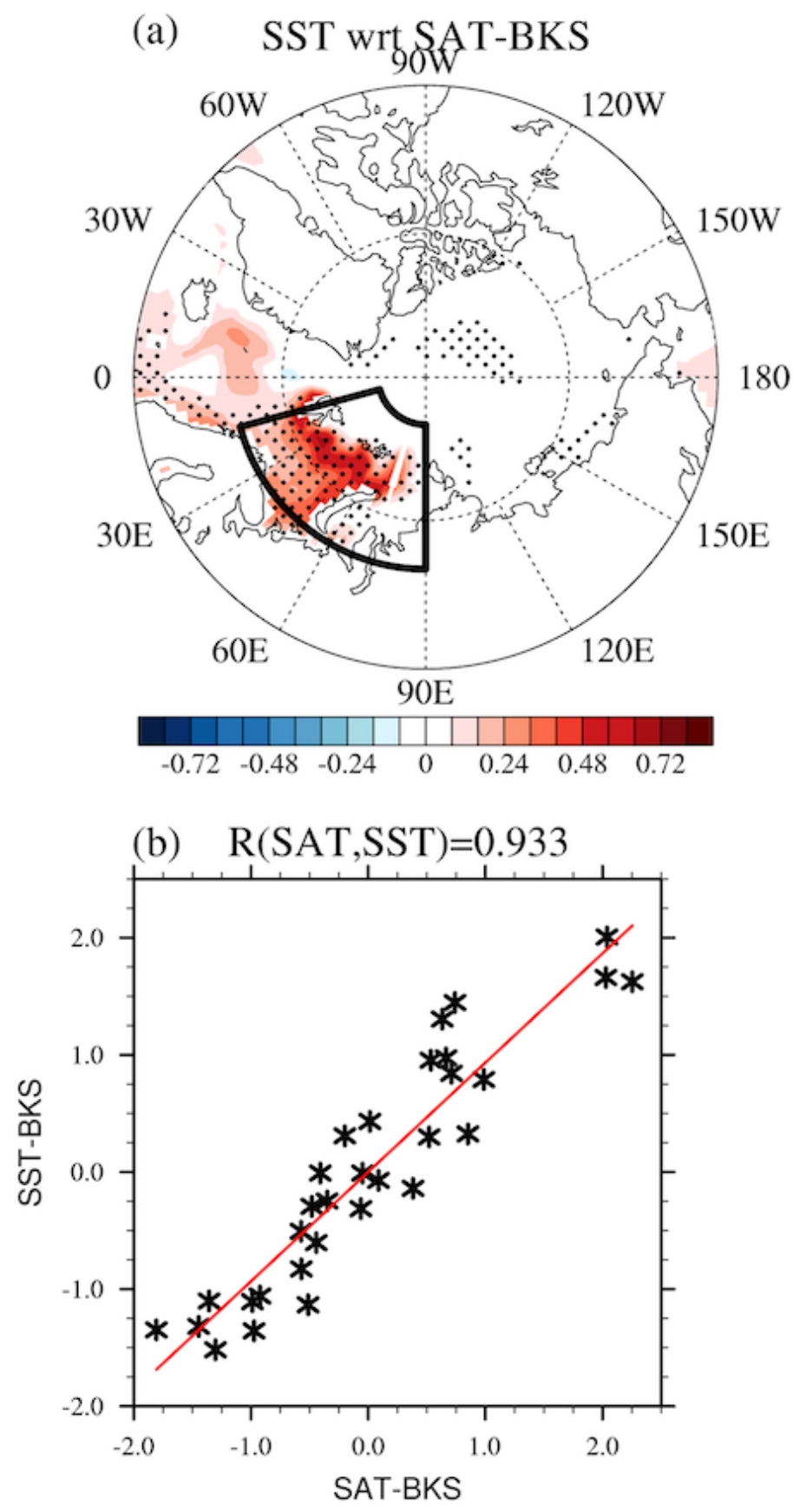

Figure 5

(a) Regressions of the winter SST trend $(\mathrm{K} / 10 \mathrm{yr})$ on the normalized winter SAT trend averaged over the Barents-Kara Seas. Dotted areas denote anomalies that are significant at the $95 \%$ confidence level according to the Student's t-test. (b) Scatterplots of the normalized winter SAT trend against the normalized winter SST trend averaged over the Barents-Kara Seas in 31 IPSL-CM6A-LR ensemble members. Note: The designations employed and the presentation of the material on this map do not 
imply the expression of any opinion whatsoever on the part of Research Square concerning the legal status of any country, territory, city or area or of its authorities, or concerning the delimitation of its frontiers or boundaries. This map has been provided by the authors.
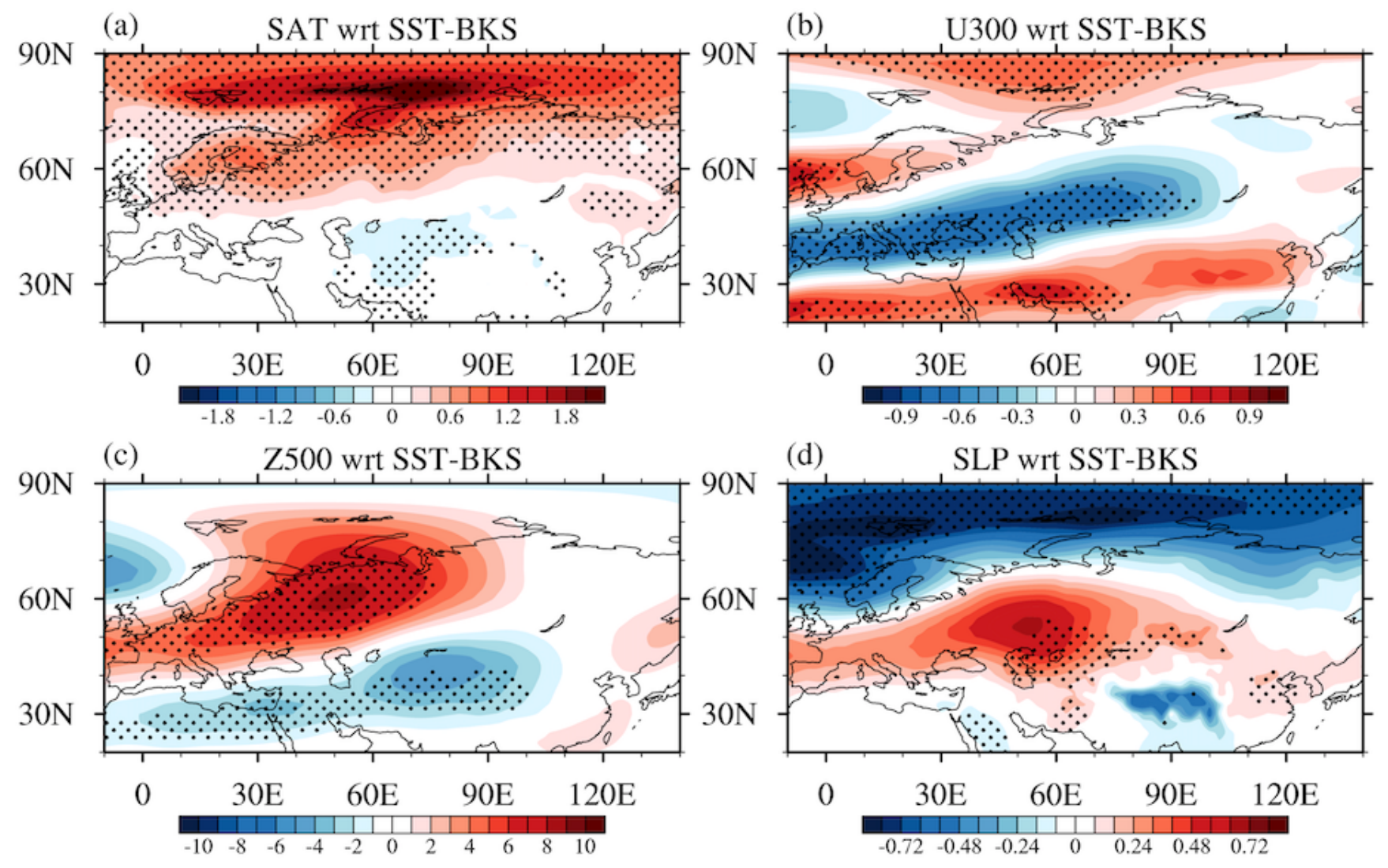

Figure 6

Regressions of the trends of winter (a) SAT (K/10 yr), (b) U300 (m s-1/10 yr), (c) Z500 (m/10 yr) and (d) SLP ( $\mathrm{hPa} / 10 \mathrm{yr}$ ) on the normalized winter SST trend averaged over the Barents-Kara Seas. Dotted areas denote anomalies that are significant at the $95 \%$ confidence level according to the Student's t-test. Note: The designations employed and the presentation of the material on this map do not imply the expression of any opinion whatsoever on the part of Research Square concerning the legal status of any country, territory, city or area or of its authorities, or concerning the delimitation of its frontiers or boundaries. This map has been provided by the authors. 


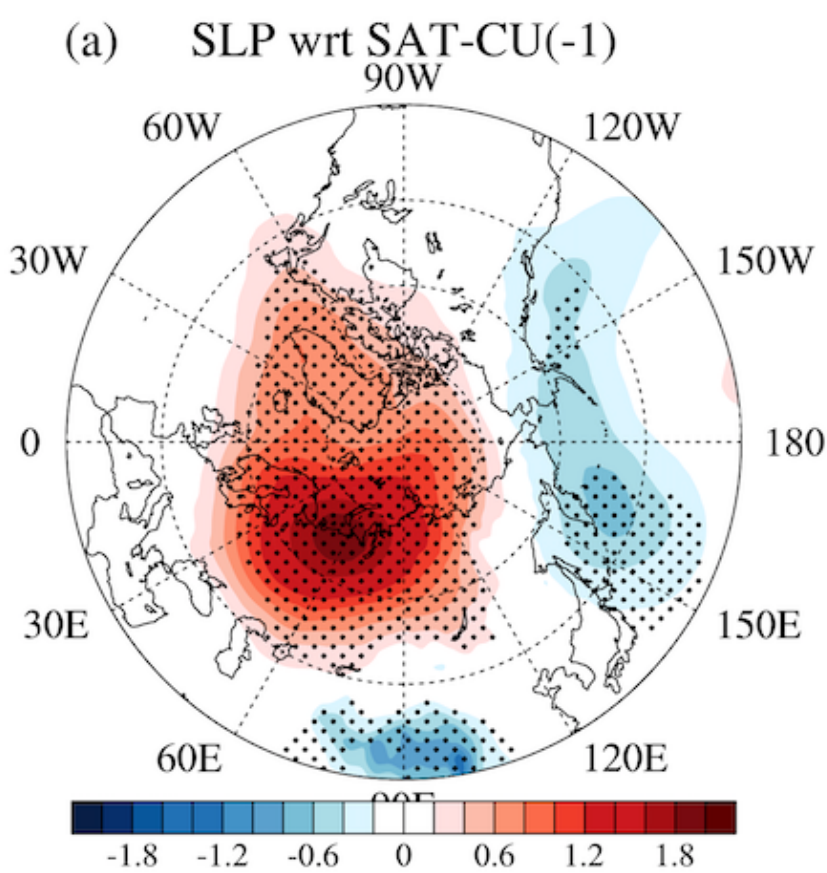

(c)

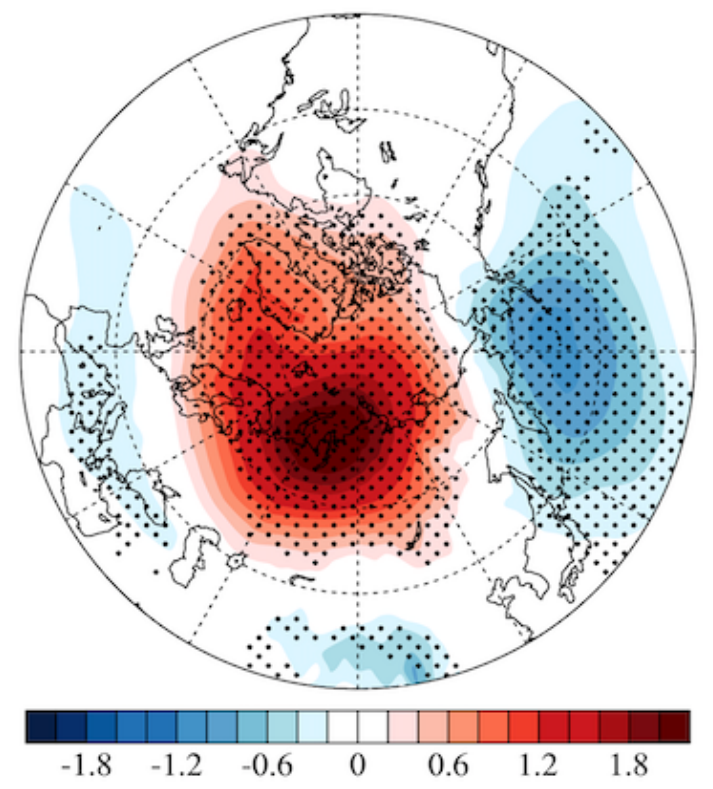

(b) Z500 wrt SAT-CU(-1)

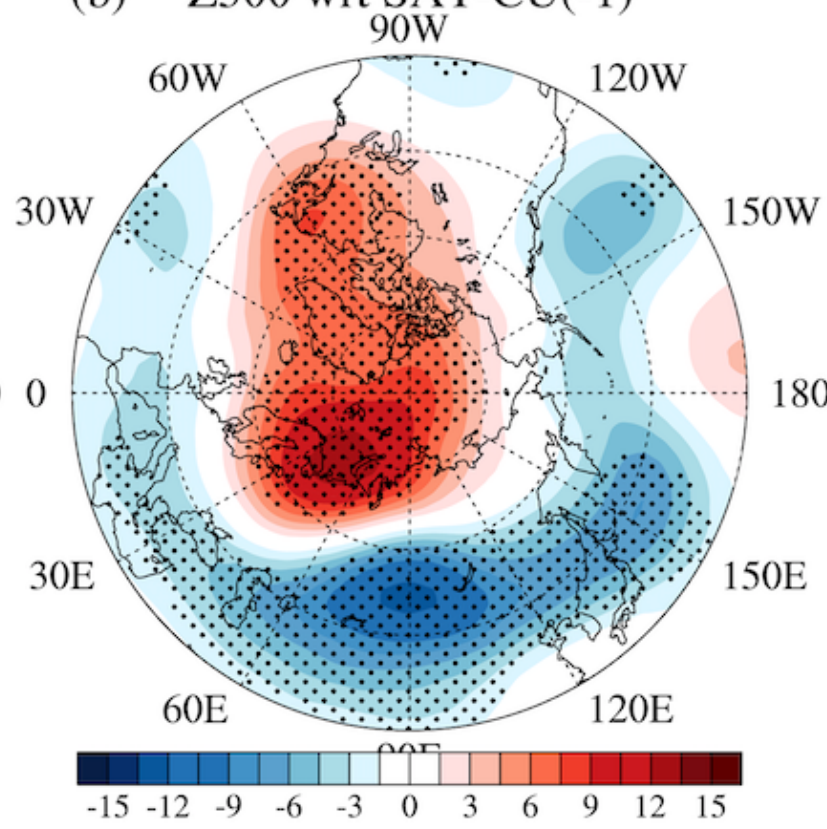

(d)
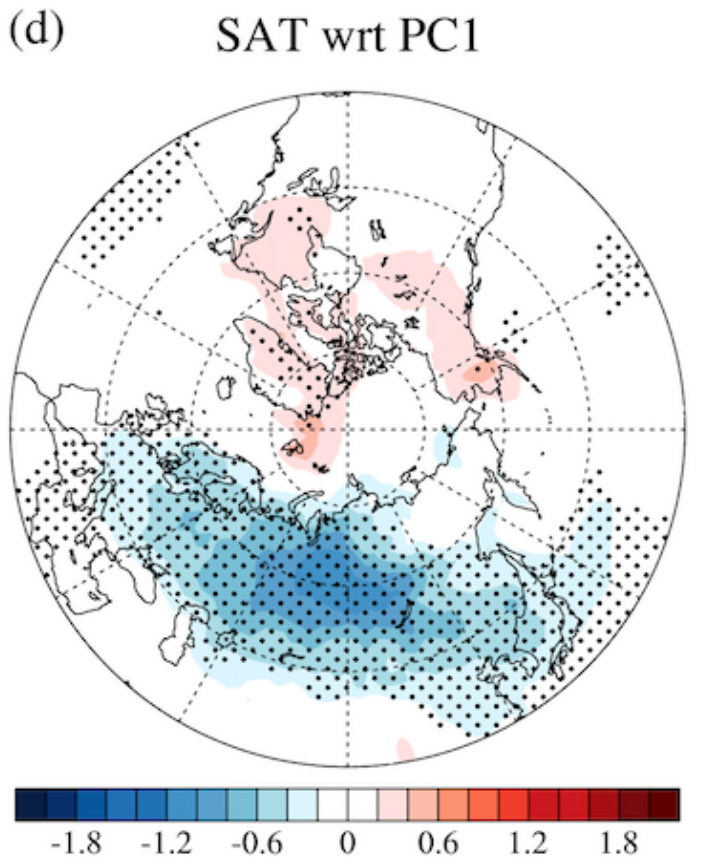

\section{Figure 7}

$(\mathrm{a}, \mathrm{b})$ Regressions of the trends of winter (a) SLP (hPa/10 yr) and (b) Z500 (m/10 yr) on the normalized winter SAT trend averaged over central Eurasia. (c, d) Regressions of the trends of winter (c) SLP (hPa/10 $\mathrm{yr}$ ) and (d) SAT (K/10 yr) upon the normalized PC1 of EOF modes of winter SLP trends in the domain of Eurasia $\left(30^{\circ}-90^{\circ} \mathrm{N}, 0^{\circ}-180^{\circ} \mathrm{E}\right)$. Dotted areas denote anomalies that are significant at the $95 \%$ confidence level according to the Student's t-test. Note: The designations employed and the presentation of the 
material on this map do not imply the expression of any opinion whatsoever on the part of Research Square concerning the legal status of any country, territory, city or area or of its authorities, or concerning the delimitation of its frontiers or boundaries. This map has been provided by the authors.
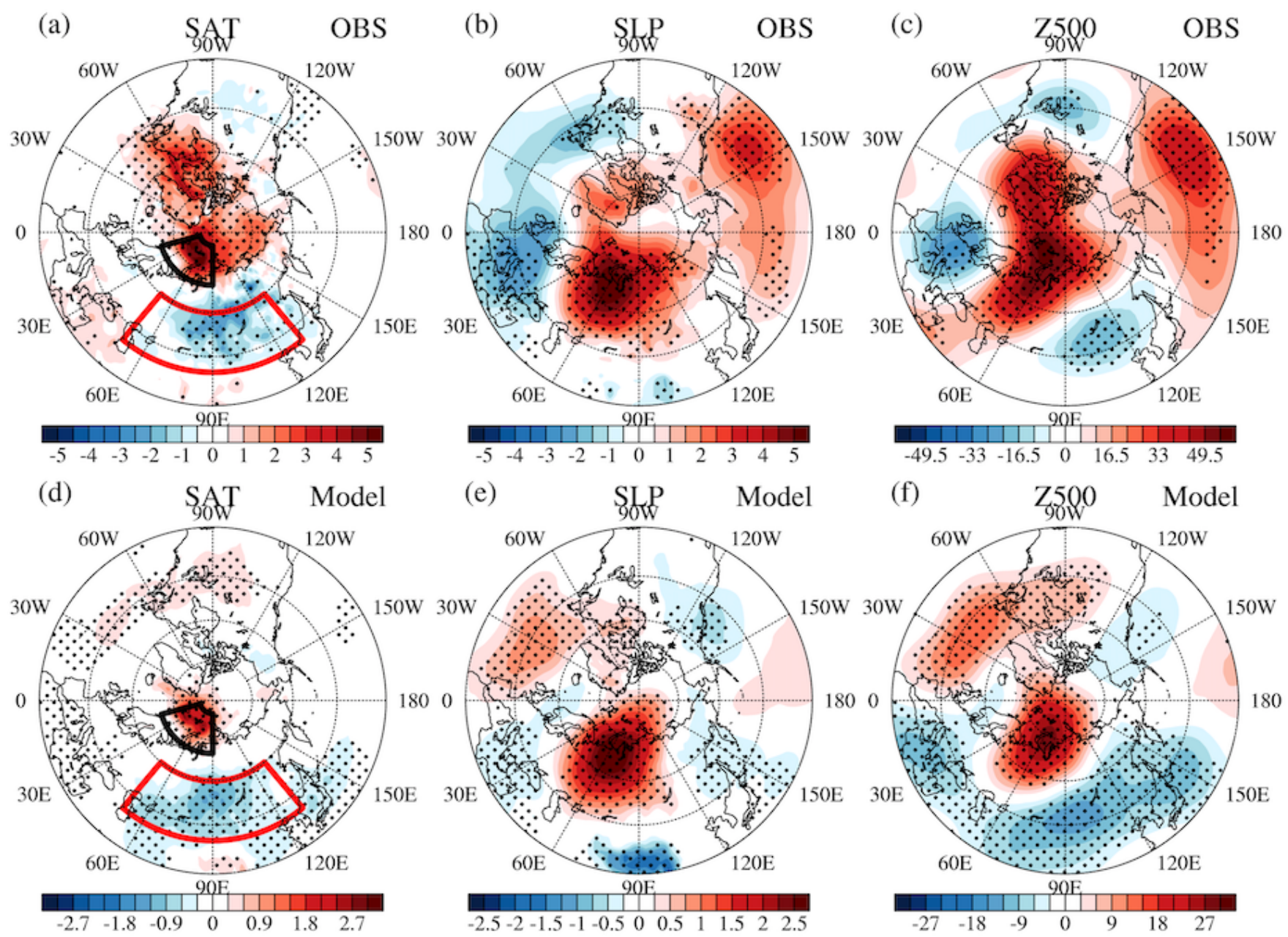

\section{Figure 8}

$(\mathrm{a}-\mathrm{c})$ Observed trends of winter (a) SAT (K/10 yr), (b) SLP (hPa/10 yr) and (c) Z500 (m/10 yr) during 1991-2014. (d-f) Composite trends of winter (d) SAT (K/10 yr), (e) SLP (hPa/10 yr) and (f) Z500 (m/10 yr) for the five selected IPSL-CM6A-LR ensemble members. Dotted areas indicate the $90 \%$ confidence level according to the two-tailed nonparametric Monte Carlo bootstrap significance test. Note: The designations employed and the presentation of the material on this map do not imply the expression of any opinion whatsoever on the part of Research Square concerning the legal status of any country, territory, city or area or of its authorities, or concerning the delimitation of its frontiers or boundaries. This map has been provided by the authors. 


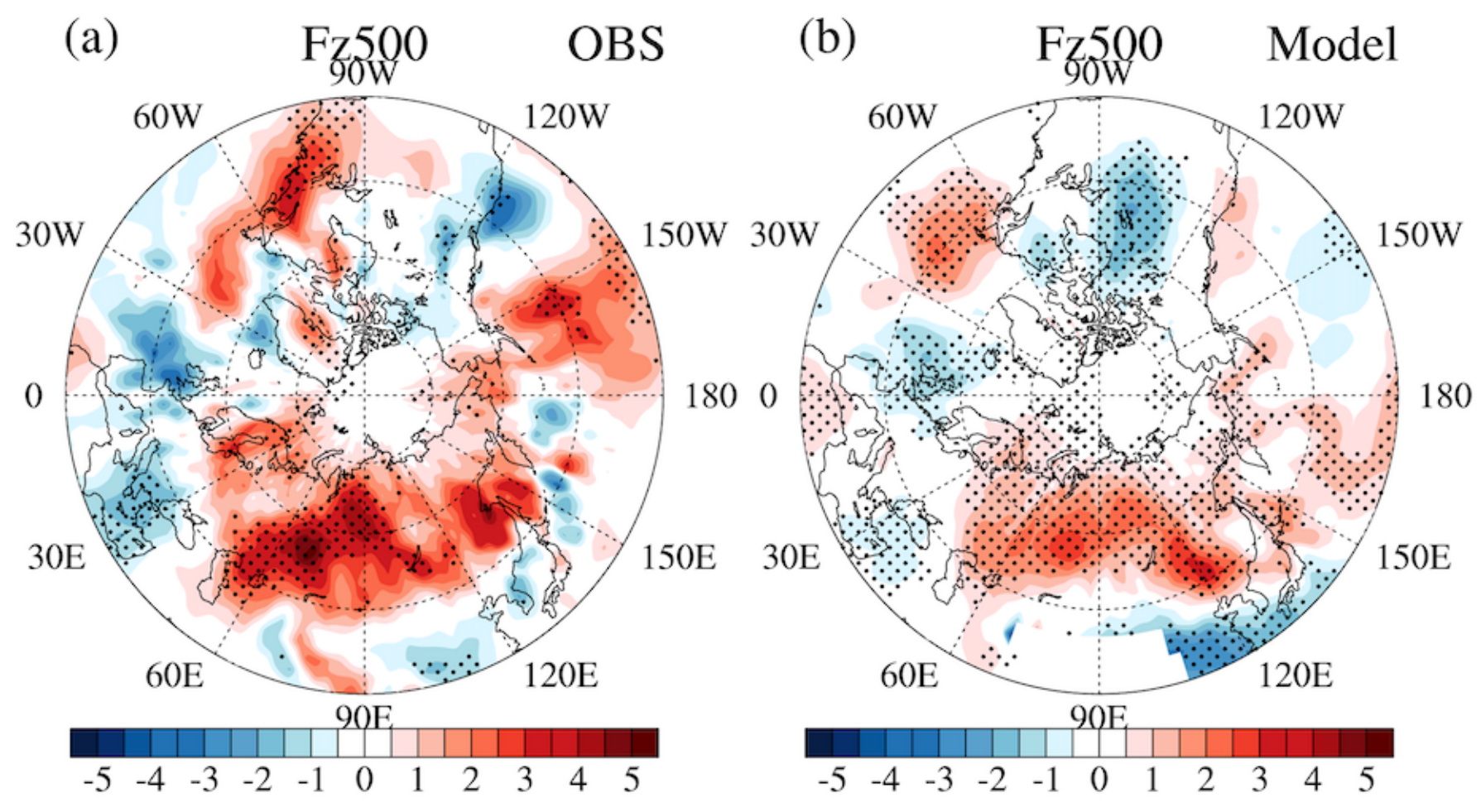

\section{Figure 9}

Trends in the vertical component of SWAF (102 m2 s-2/10 yr) at $500 \mathrm{hPa}$ during winter for the period 1991-2014 in the (a) observation and (b) five selected IPSL-CM6A-LR ensemble members. Dotted areas indicate the $90 \%$ confidence level according to the two-tailed nonparametric Monte Carlo bootstrap significance test. Note: The designations employed and the presentation of the material on this map do not imply the expression of any opinion whatsoever on the part of Research Square concerning the legal status of any country, territory, city or area or of its authorities, or concerning the delimitation of its frontiers or boundaries. This map has been provided by the authors. 